\title{
Smoking associated with TSH receptor antibody and serum IL-17A elevation in hyperthyroid Graves' disease
}

${ }^{1}$ Dr. Ildikó Molnár, ${ }^{2}$ Dr. Ilona Bohaty, ${ }^{1}$ Éva Somogyiné-Vári

${ }^{1}$ Immunoendocrinology and Osteoporosis Centre, EndoMed, ${ }^{2}$ Regional Centre of Hungarian

National Blood Transfusion Service, Bem tér 19., Debrecen, Hungary

Introduction

Graves' ophthalmopathy is an autoimmune thyroid disease with local orbital inflammations and immune processes leading to periorbital edema, proptosis, corneal ulcers and loss of visual fields. Proinflammatory cytokines, such as IL-1, IL-6 and TNF $\alpha$ are involved in the orbital damages. Th17 cells are newly discovered CD4+ T cells producing predominantly IL-17A cytokine. IL-17A act as proinflammatory cytokine and chemokine. The role of IL-17A is demonstrated in acute and chronic inflammation, autoimmune and allergic diseases, as well as in the defense mechanism. The worsening allergic diseases, as well as in the defense mechanism. The worsening
effect of smoking on thyroid gland size and risk of Graves' ophthalmopathy has been confirmed by several reports.

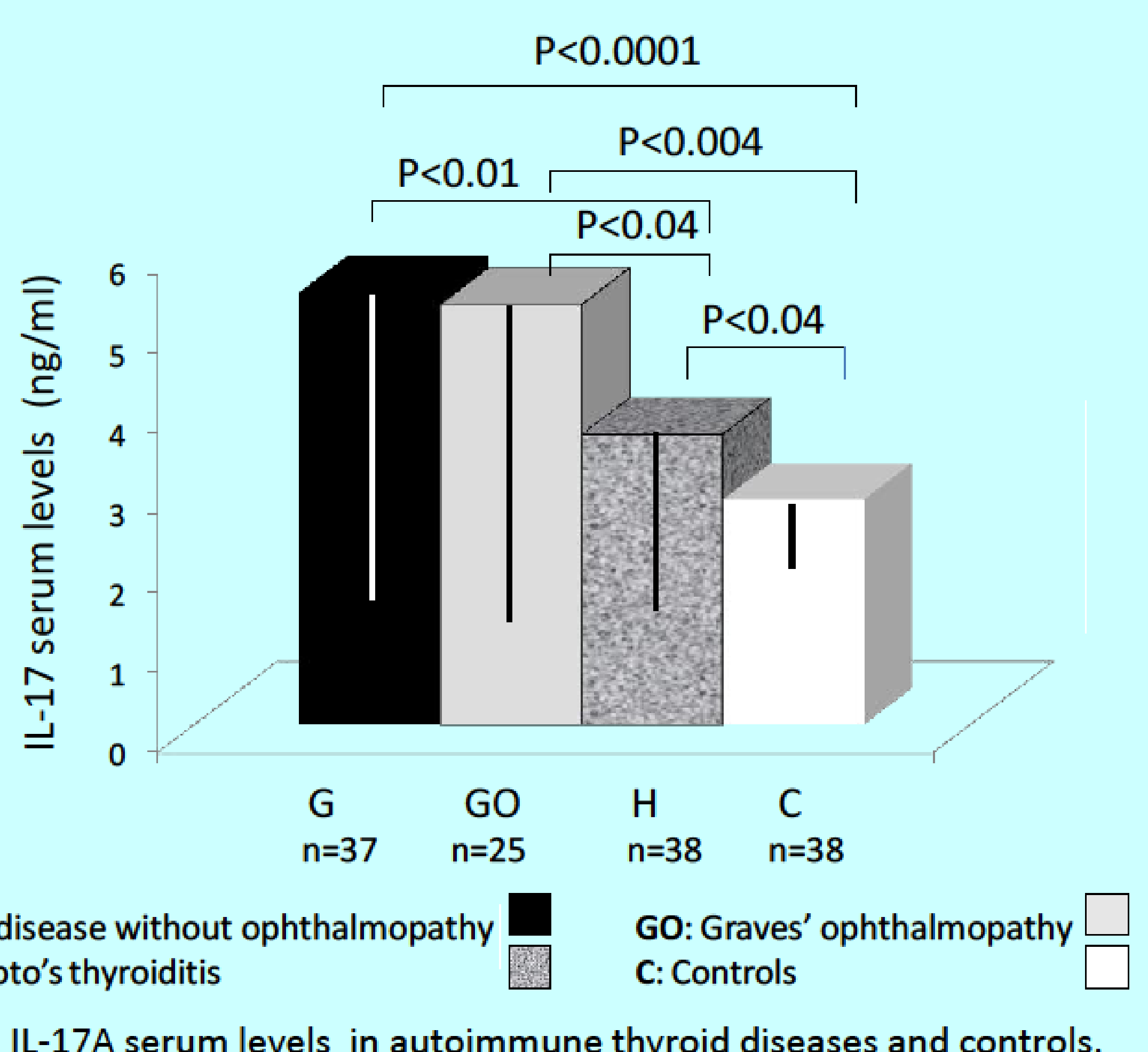

igure 1: IL-17A serum levels in autoimmune thyroid diseases and controls.

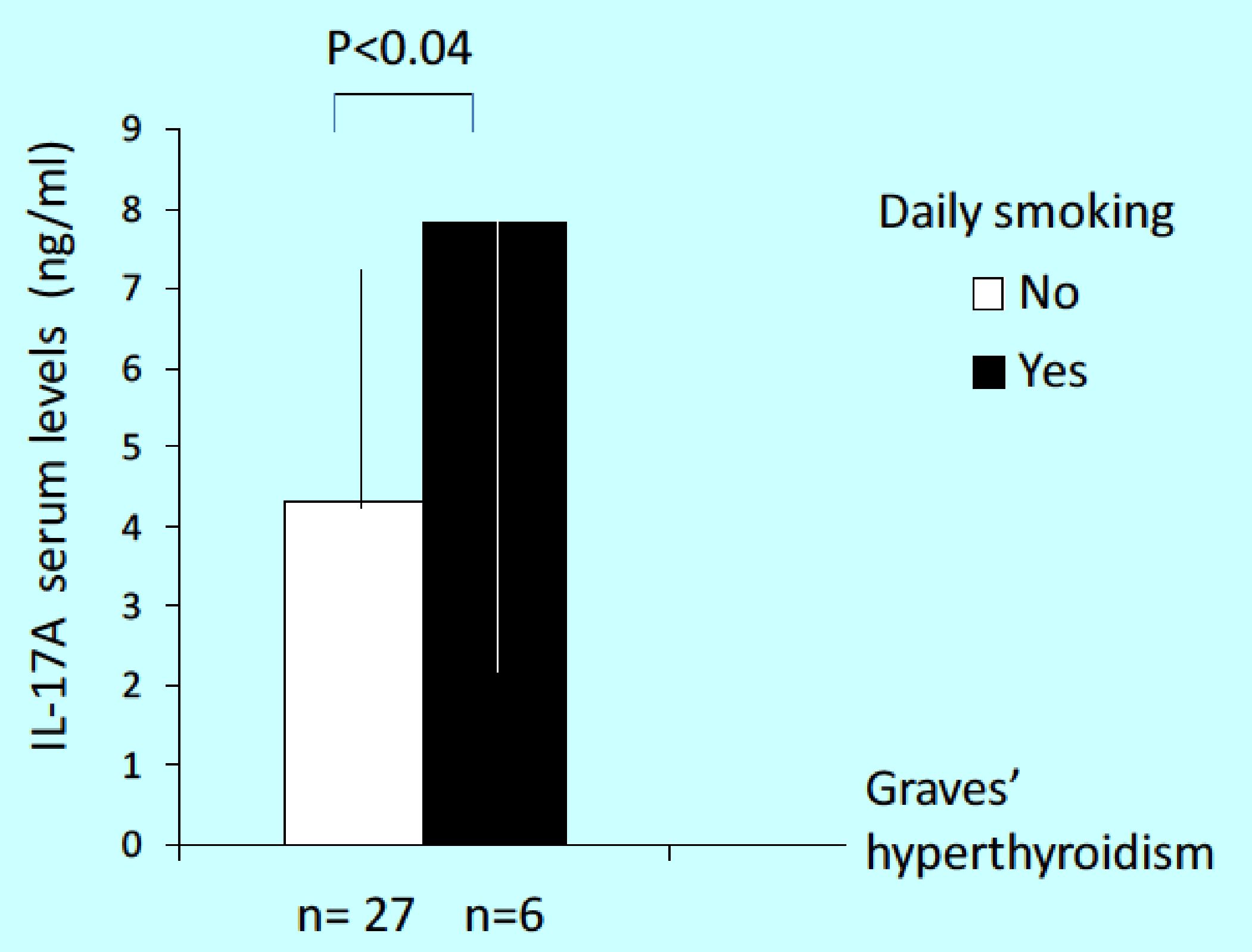

Figure 4: Effect of smoking on IL-17A in hyperthyroid Graves' disease.

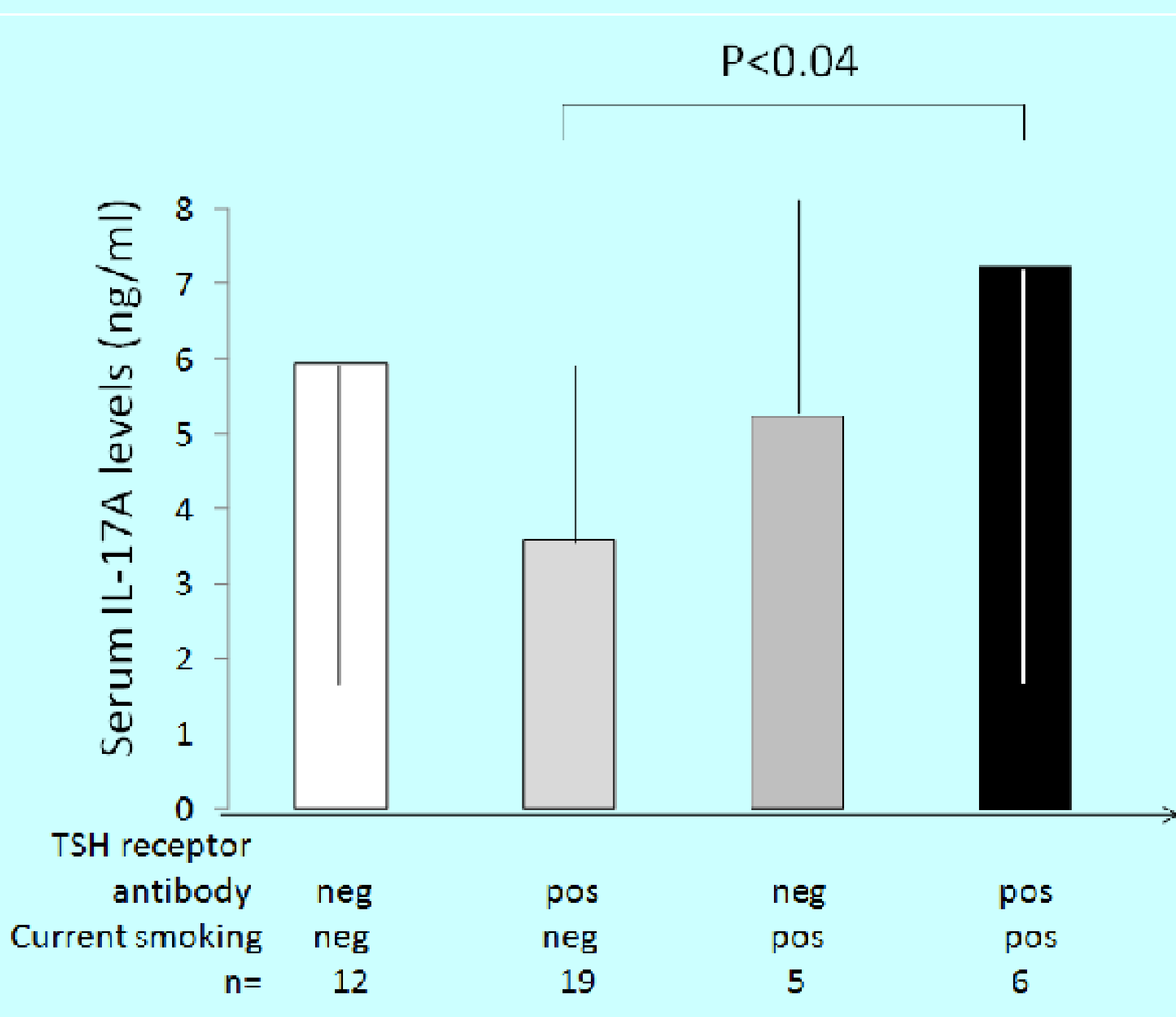

Figure 7: Effect of smoking and TSH receptor antibody serum levels on IL-17A serum levels in Graves' disease.

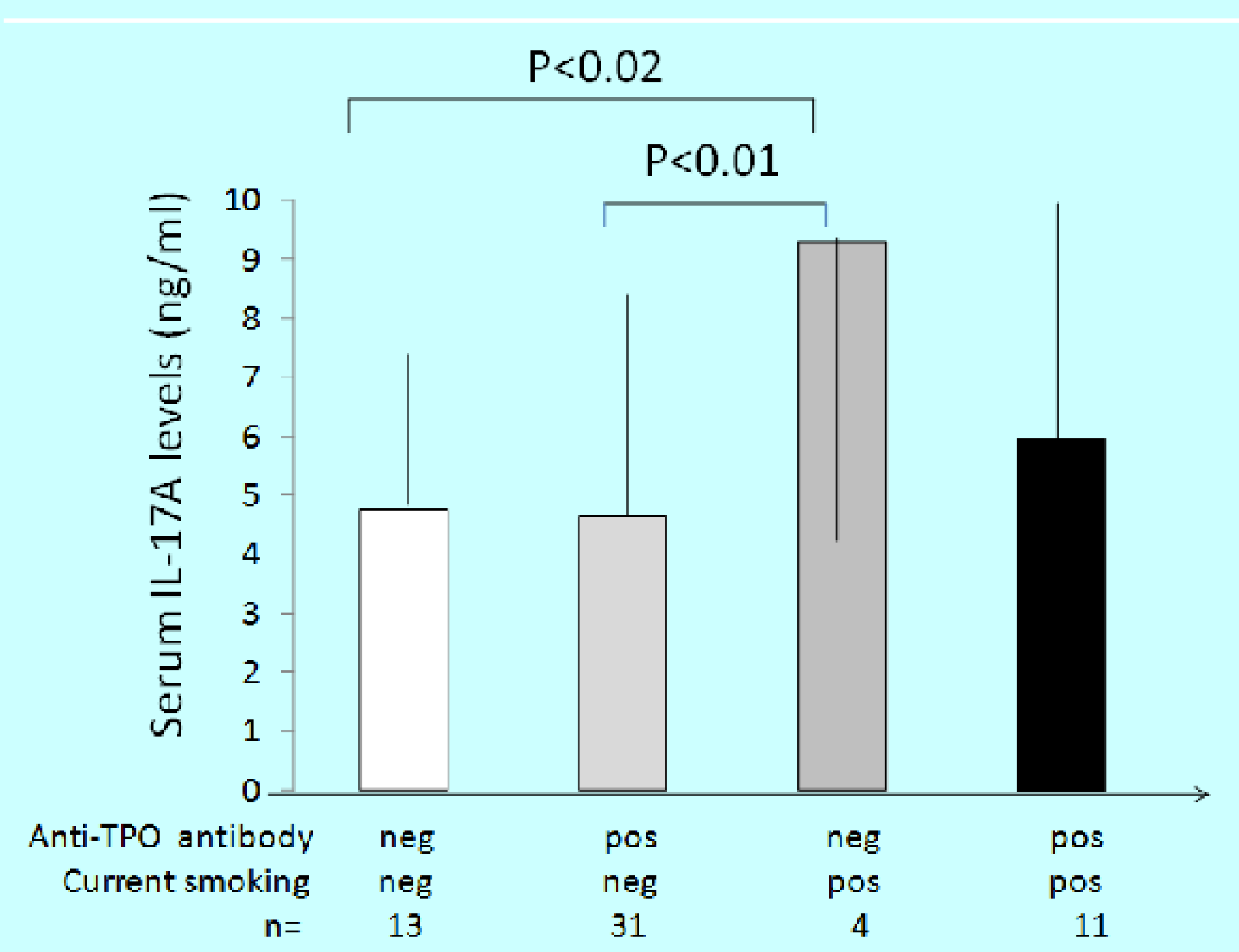

Figure 8: Effect of smoking and anti-thyroid peroxidase (TPO) antibody serum levels on IL-17A serum levels in Graves' disease.

\section{Purpose of the study}

To investigate the IL-17A serum levels in autoimmune thyroid disease and controls.

To demonstrate smoking effect on IL-17A serum levels.

To study the relationships among smoking and serum IL-17A, TSH receptor antibody, anti-TPO, anti-Htg levels in Graves' disease.

To demonstrate the influencing effect of smoking on IL-17A serum level during thyrostatic therapy in Graves' hyperthyroidism.
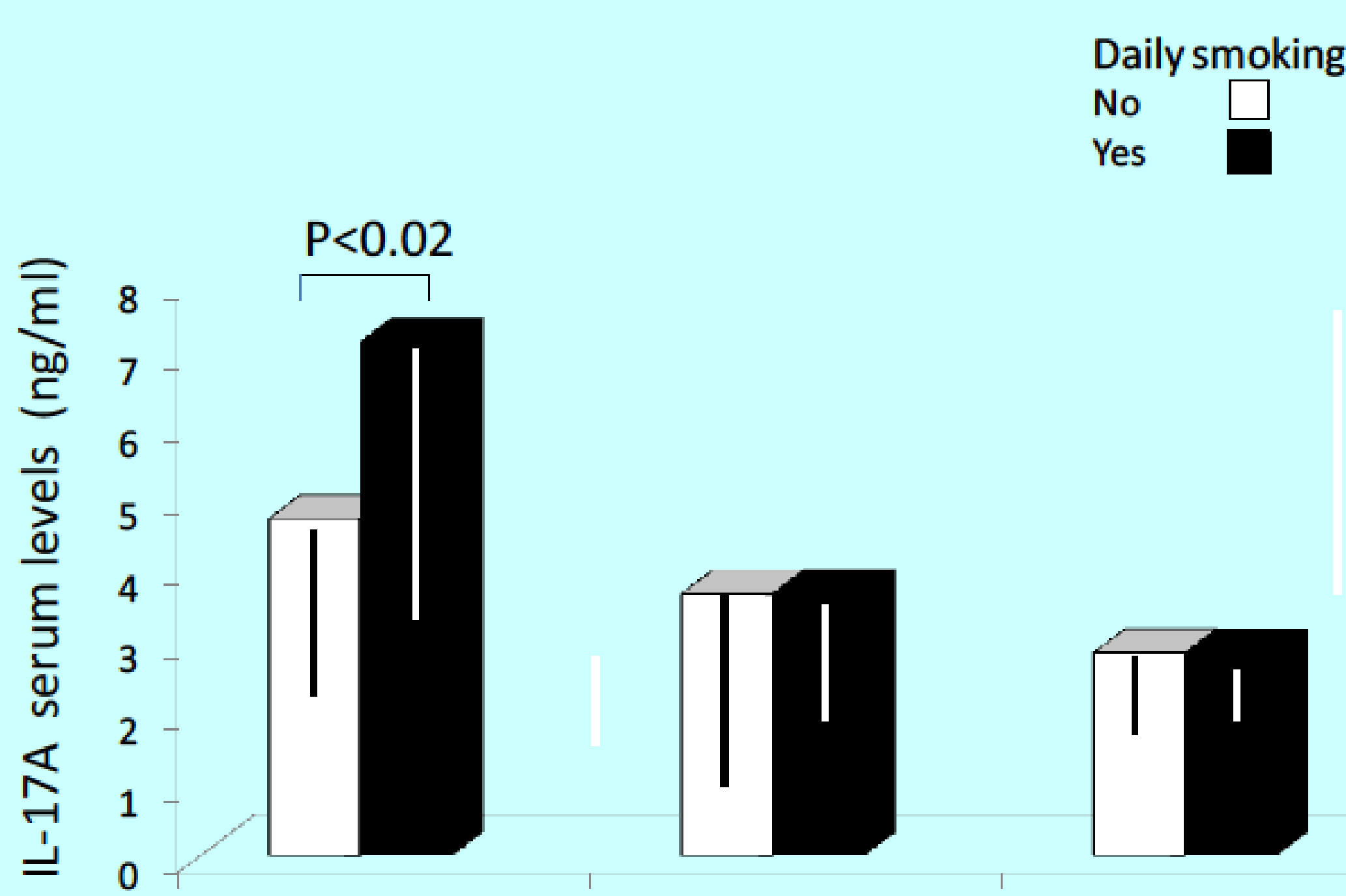

Graves' disease Hashimoto's thyroiditis Controls

Figure 2: Smoking effect on IL-17A levels in autoimmune thyroid diseases

Results
Patients and methods

One-hundred-thirty-eight patients, 62 with Grave disease ( 25 with opthalmopathy, 33 with hyperthyroidism, 17 have daily smoking), 38 with Hashimoto's thyroiditis and 38 healthy controls were investigated.

Serum IL-17A levels were measured with enzyme-linked immunosorbent assay; thyroid hormones, anti-thyroid antibodies in a fully automated way, but TSH receptor antibodies with radioimmunoassay.

Student's paired t-test was used for the statistical analysis.

ble 1: Clinical parameters in patients with autoimmune thyroid diseases and controls.

\begin{tabular}{|c|c|c|c|c|}
\hline \multirow[b]{2}{*}{ Clinical parameters } & \multicolumn{4}{|c|}{ Patient groups } \\
\hline & $\begin{array}{l}\text { Graves' } \\
\text { disease } \\
(n=37)\end{array}$ & $\begin{array}{c}\text { Graves' } \\
\text { ophthalmopathy } \\
(n=25)\end{array}$ & $\begin{array}{c}\text { Hashimoto's } \\
\text { thyroiditis } \\
(\mathrm{n}=38)\end{array}$ & $\begin{array}{l}\text { Control } \\
(n=38)\end{array}$ \\
\hline $\begin{array}{c}\text { Gender } \\
\text { (female/male) }\end{array}$ & $32 / 5$ & $22 / 3$ & $38 / 0$ & $34 / 4$ \\
\hline Age (years) & $41 \pm 12$ & $49 \pm 13$ & $43 \pm 11$ & $45 \pm 12$ \\
\hline Daily smoking (n) & 11 & 6 & 12 & 14 \\
\hline $\mathrm{TSH}(\mathrm{mU} / \mathrm{ll})$ & $1,65 \pm 3,6$ & $2,78 \pm 5,71$ & $3,51 \pm 5,83$ & \\
\hline $\mathrm{FT}_{4}(\mathrm{pmol} / \mathrm{l})$ & $19,8 \pm 9,49$ & $23,55 \pm 14,5$ & $15,22 \pm 3,39$ & \\
\hline $\mathrm{FT}_{3}(\mathrm{pmol} / \mathrm{l})$ & $8,38 \pm 5,7$ & $8,09 \pm 7,43$ & $4,19 \pm 1,17$ & \\
\hline $\begin{array}{c}\text { TSH receptor } \\
\text { antibodies (U/I) }\end{array}$ & $\begin{array}{r}5,89 \\
\pm 8,66 \\
\end{array}$ & $\begin{array}{r}10,61 \\
\pm 12,33 \\
\end{array}$ & & \\
\hline $\begin{array}{l}\text { Anti-TPO antibodies } \\
\text { (IU/I) }\end{array}$ & $\begin{array}{r}359,47 \\
\pm 414,51 \\
\end{array}$ & $\begin{array}{c}298,64 \\
\pm 410,41 \\
\end{array}$ & $\begin{array}{r}480,12 \\
\pm 313,8 \\
\end{array}$ & \\
\hline $\begin{array}{l}\text { Anti-Htg antibodies } \\
\text { (IU/I) }\end{array}$ & $\begin{array}{r}196,72 \\
\pm 322,8 \\
\end{array}$ & $\begin{array}{r}34,34 \\
\pm 32,1 \\
\end{array}$ & $\begin{array}{r}433,14 \\
\pm 976,92 \\
\end{array}$ & \\
\hline $\mathrm{IL}-17 \mathrm{~A}(\mathrm{ng} / \mathrm{ml})$ & $5,43 \pm 3,62^{\mathrm{a}, \mathrm{b}}$ & $5,28 \pm 3,8^{\mathrm{c}, \mathrm{d}}$ & $3,65 \pm 2,22^{b, d, e}$ & $2,83 \pm 0,73 a, c, c e$ \\
\hline
\end{tabular}

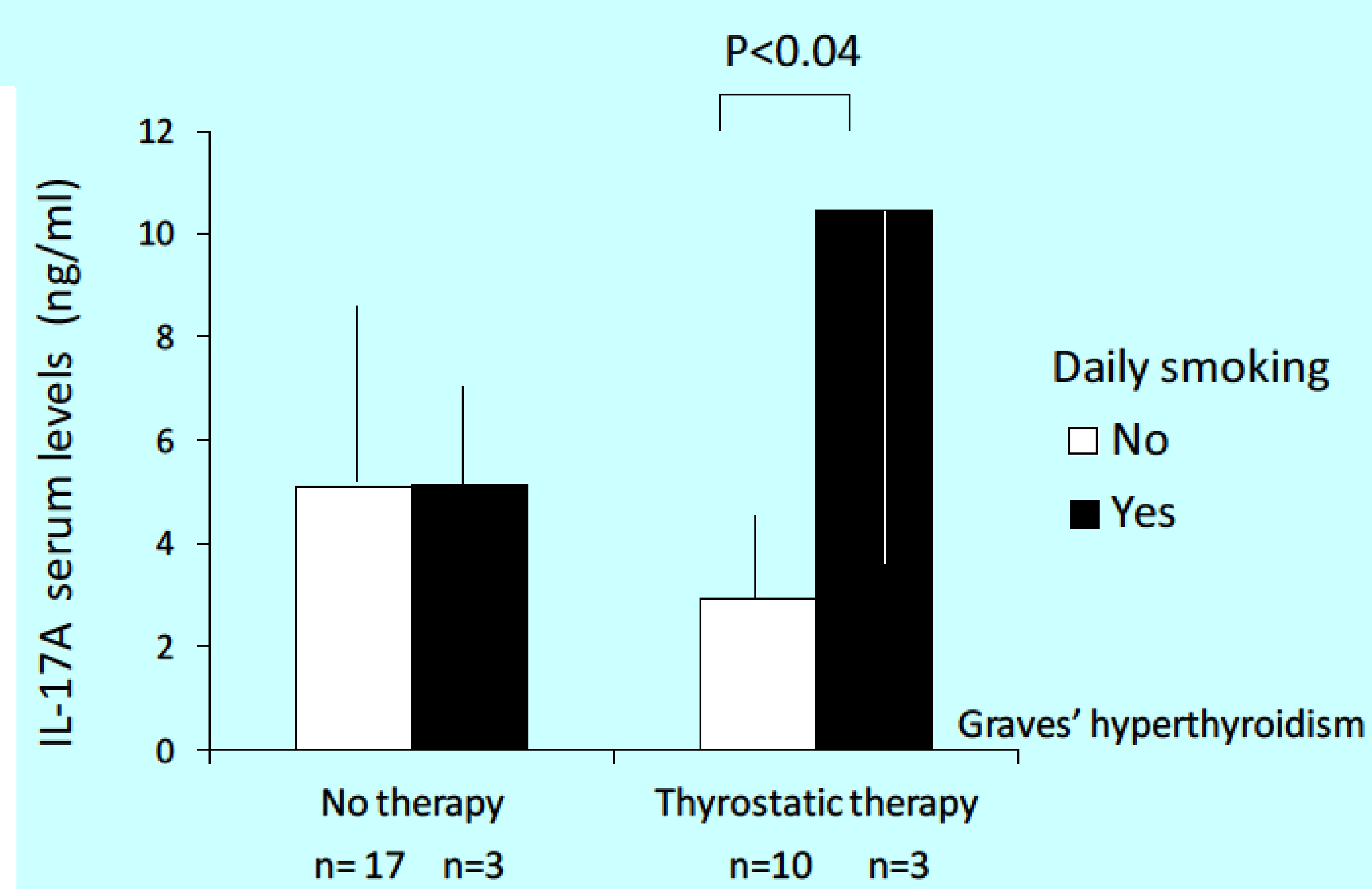

Figure 3: Effect of thyrostatic therapy and smoking on IL-17A levels in Graves' hyperthyroidism.

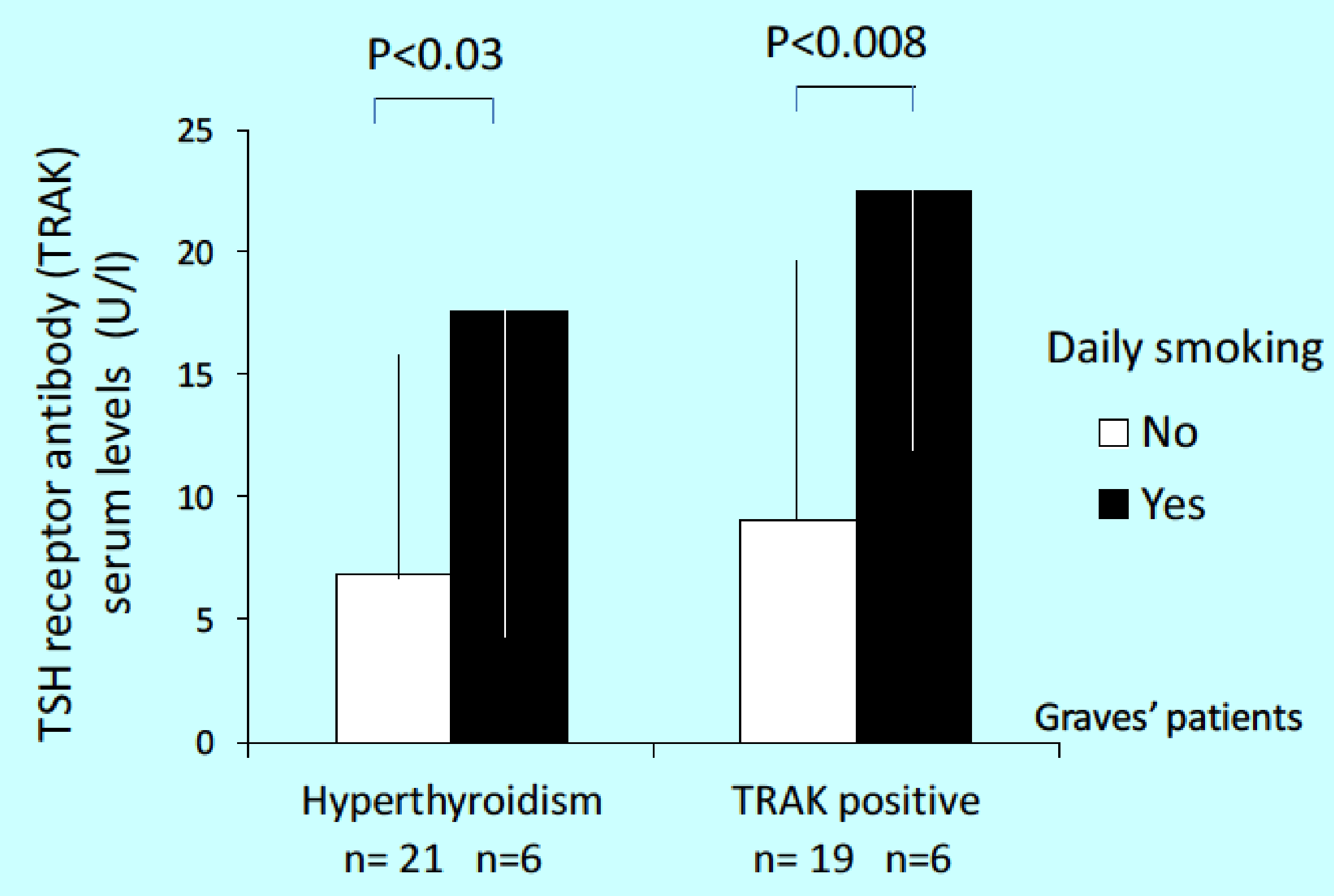

Figure 5: Smoking was connected to higher TSH receptor antibody evels in Graves' disease with hyperthyroidism or TSH receptor antibody (TRAK) positivity.

\section{Conclusions}

IL-17A cytokine was associated rather with hyperthyroid Graves' disease than in Hashimoto's thyroiditis.

$>$ Smoking demonstrated aggravating effect on IL-17A serum levels.

$>$ Smoking was associated with higher IL-17A and TSH receptor, antiTPO, anti-Htg antibody serum levels in Graves' disease.

$>$ The worsening effect of smoking may participate in Graves' ophthalmopathy via IL-17A and TSH receptor antibody elevation.

$>$ Smoking can influence the low remission rate of Graves' ophthalmopathy through IL-17A elevation.

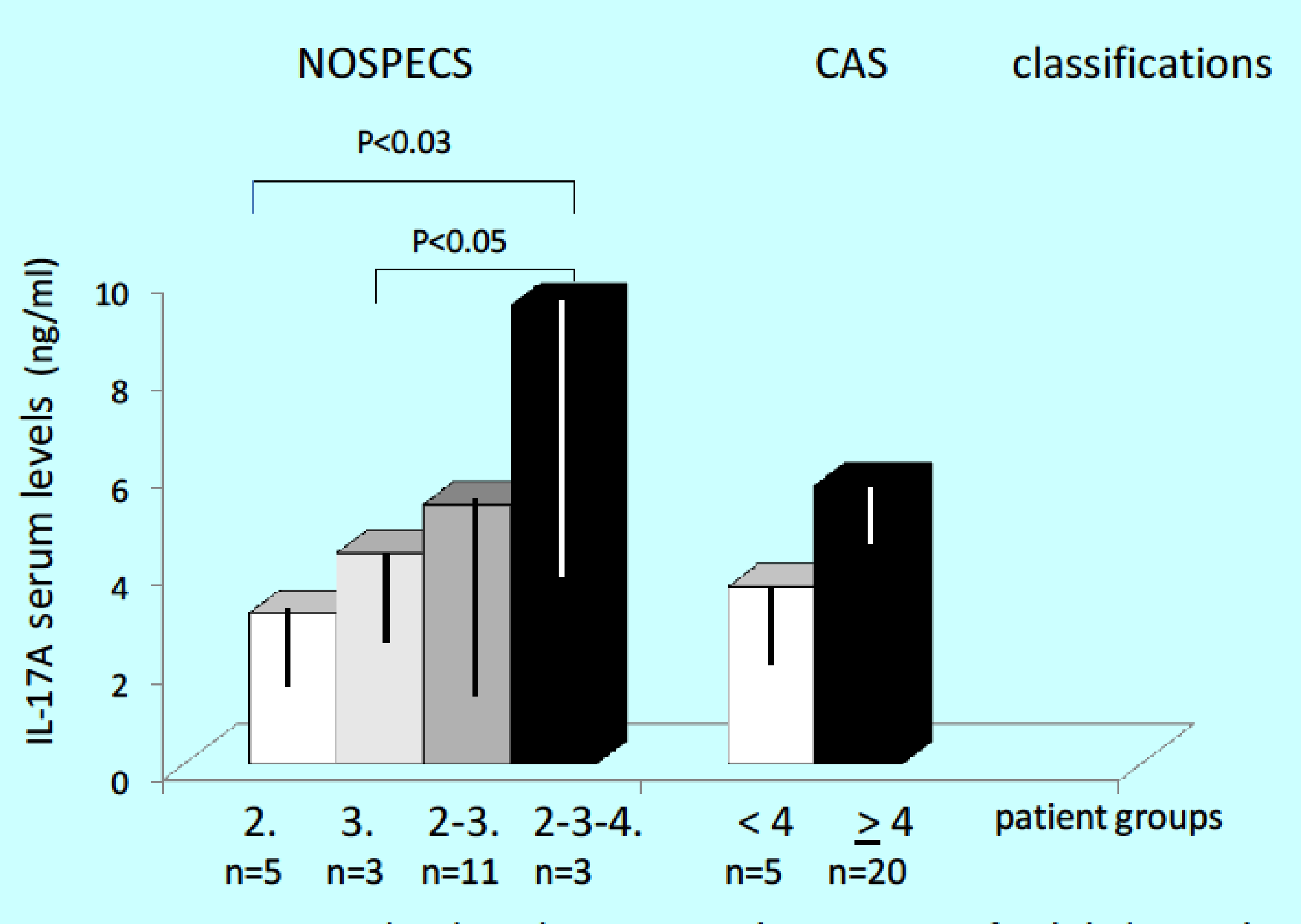

Figure $6 \mathrm{IL}-17 \mathrm{~A}$ serum levels with respect to the presence of ophthalmopathy based on NOSPECS and CAS (clinical activity score) classifications in Graves' disease.

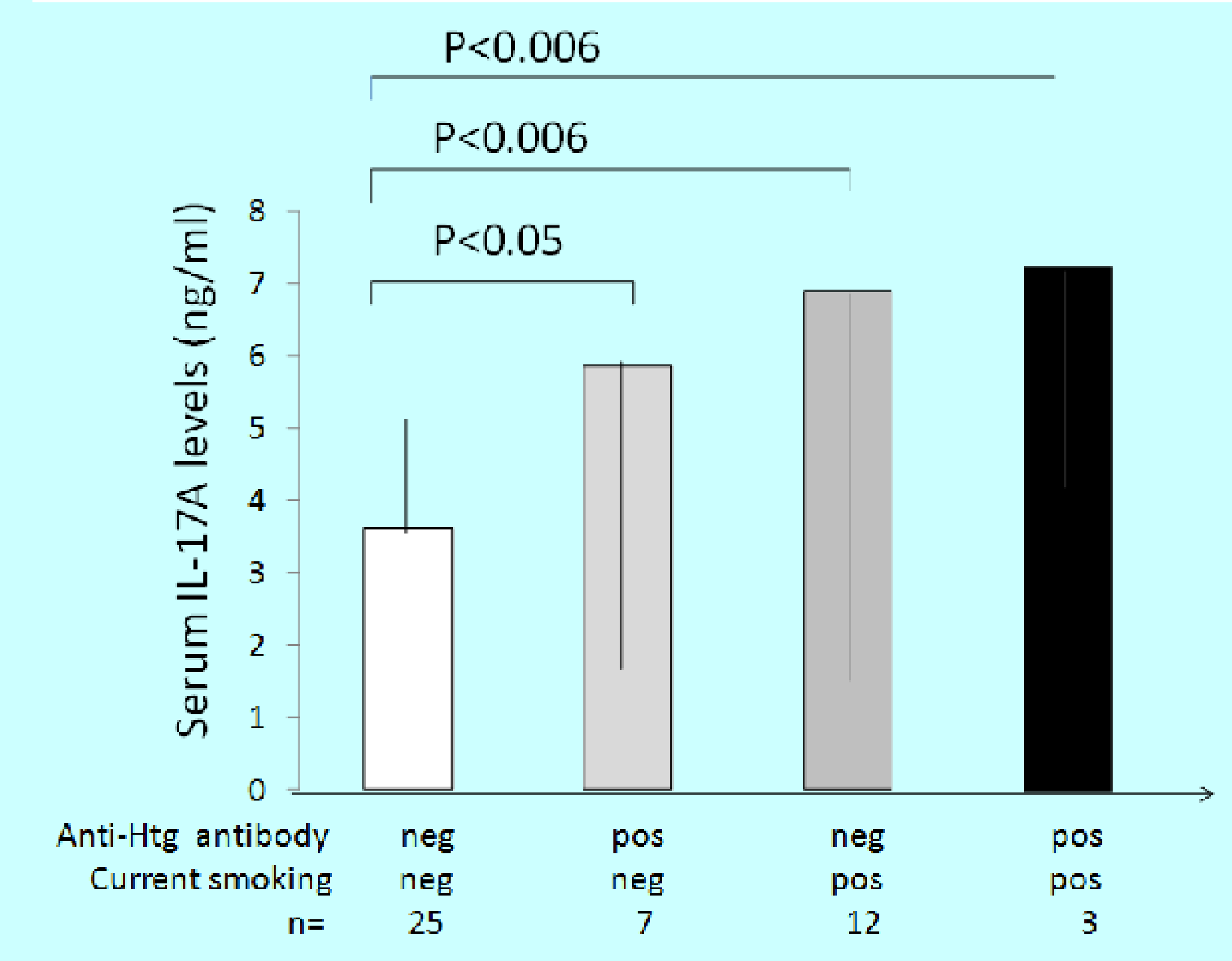

Figure 9: Effect of smoking and anti-thyroid thyroglubulin ( $\mathrm{Htg}$ ) antibody serum levels on IL-17A serum levels in Graves' disease. 